\author{
UNITED STATES \\ DEPARTMENT OF THE INTERIC \\ GEOLOGICAL SURVEY
}

UNIVERSTYY OF ILLINOIS-URBANA

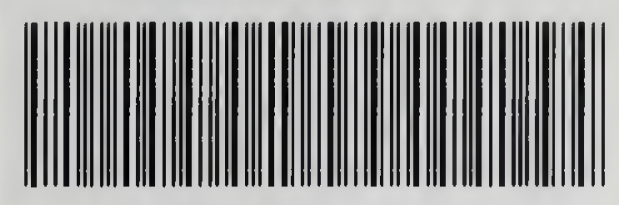

30112098721134

\title{
WATER USE IN THE DELTA COUNTIES OF MISSISSIPPI, 1983
}

\section{By J. A. Callahan}

U.S. GEOLOGICAL SURVEY

WATER-RESOURCES INVESTIGATIONS REPORT 85-4187

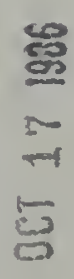

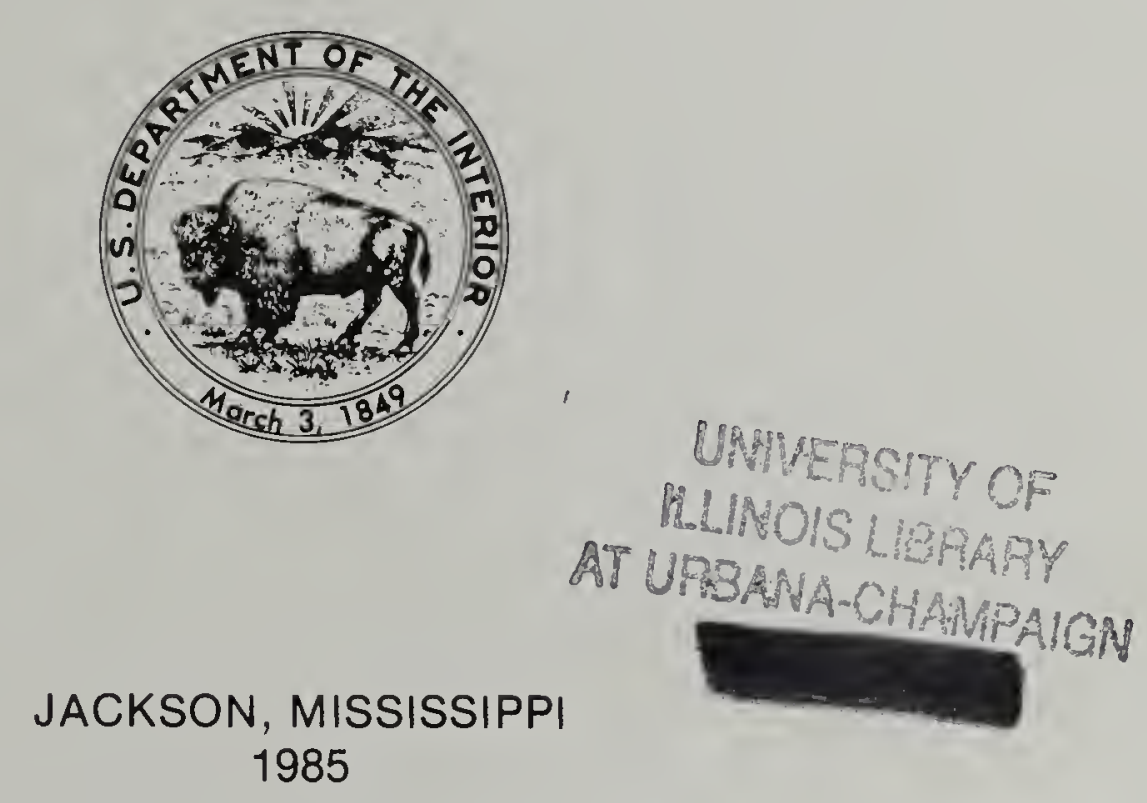

Prepared in cooperation with the

MISSISSIPPI DEPARTMENT OF NATURAL RESOURCES

BUREAU OF LAND AND WATER RESOURCES 


\section{WATER USE IN THE DELTA COUNTIES} OF MISSISSIPPI, 1983

\section{By J. A. Callahan}

U.S. GEOLOGICAL SURVEY
WATER-RESOURCES INVESTIGATIONS REPORT 85.418

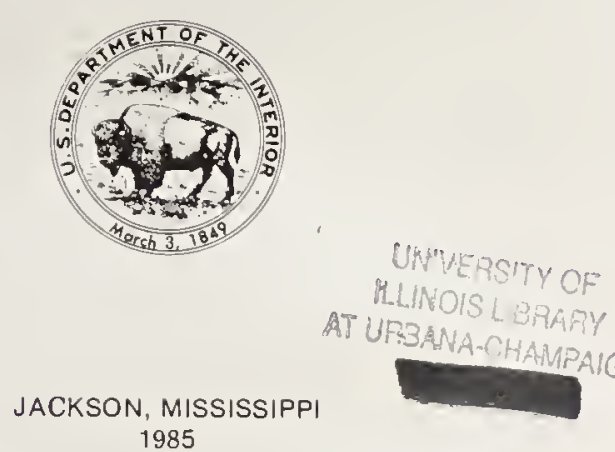

Prepared in cooperation with the

MISSISSIPPI DEPARTMENT OF NATURAL RESOURCES
BUREAU OF LAND AND WATER RESOURCES

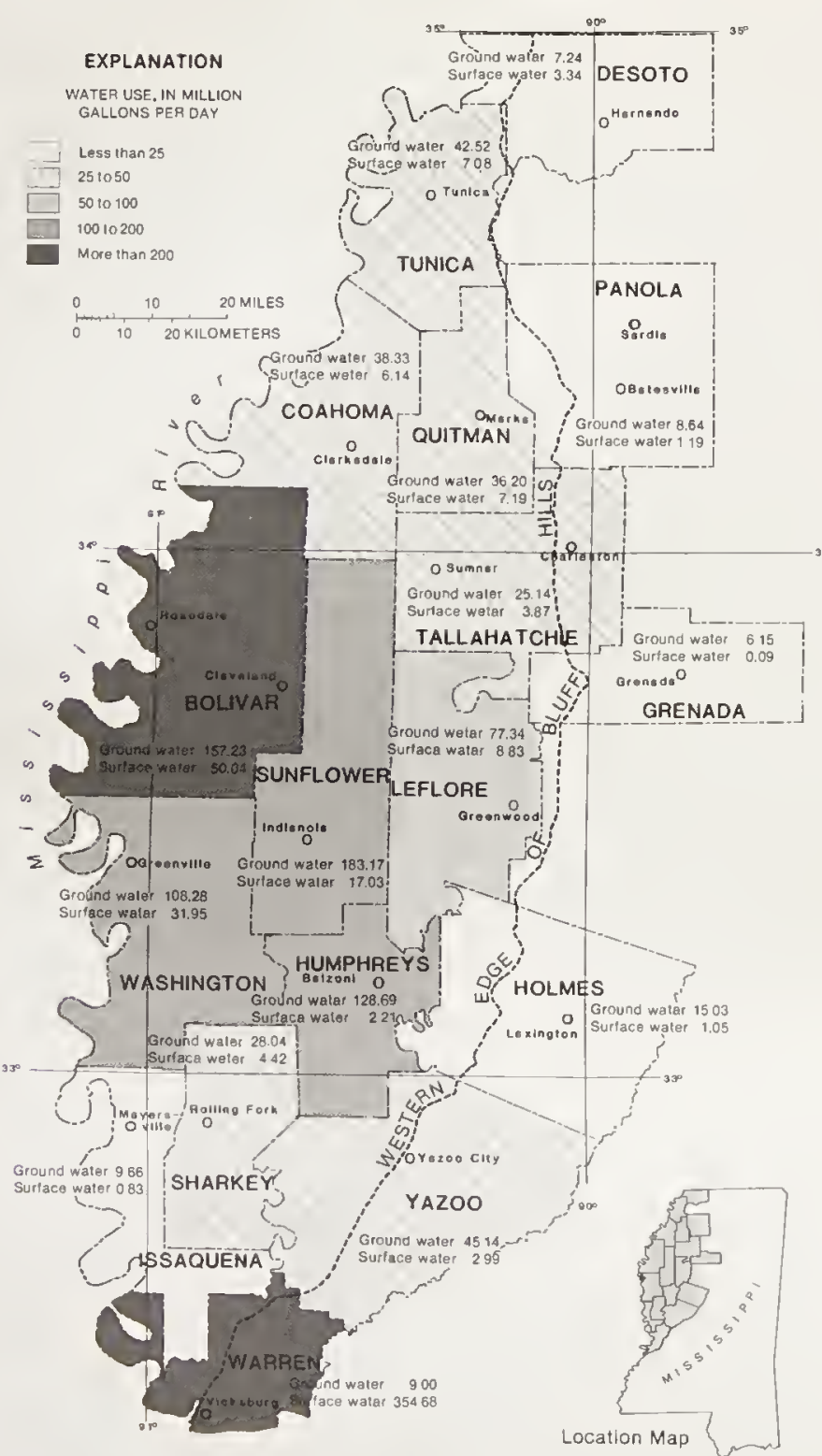

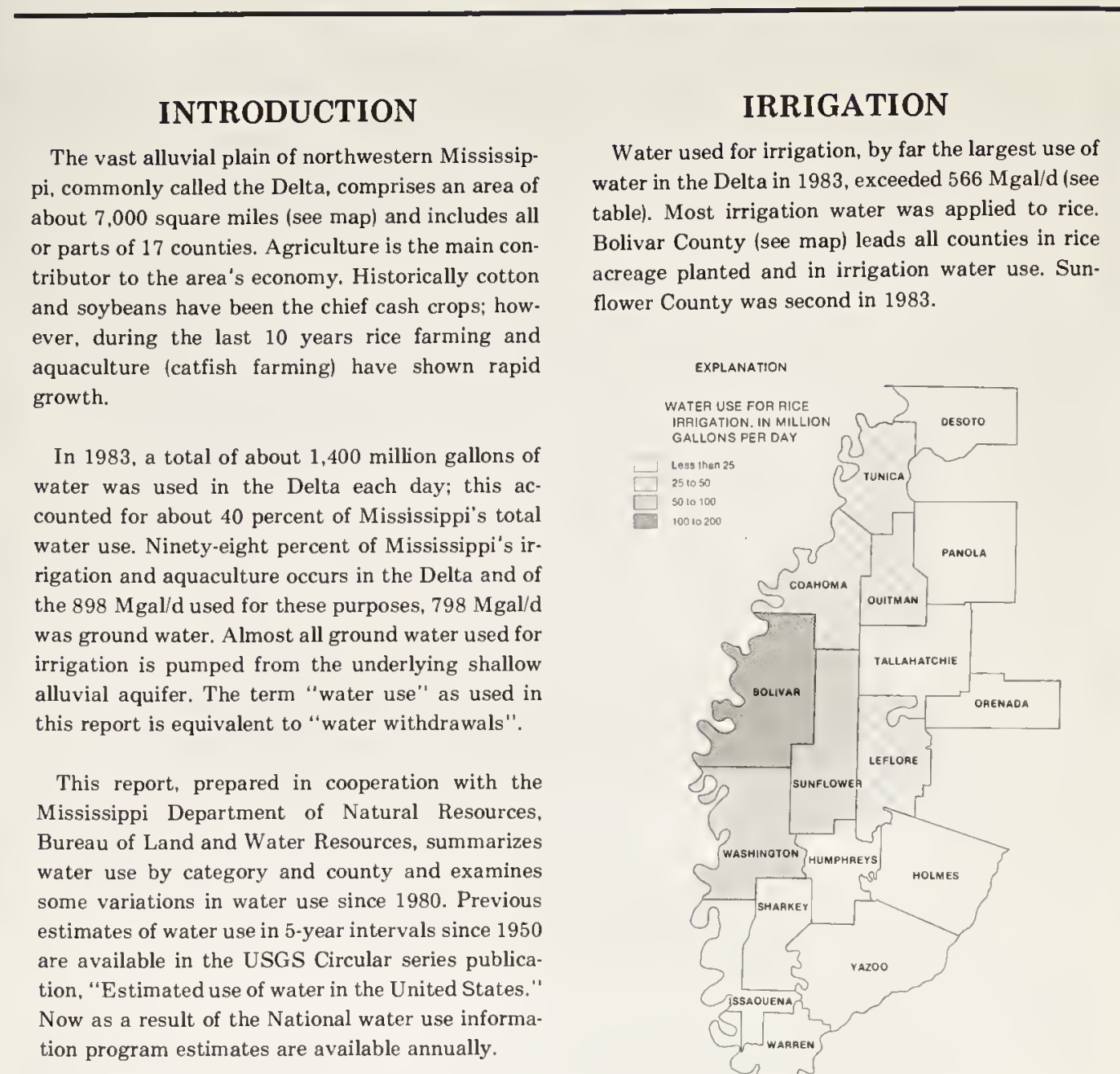

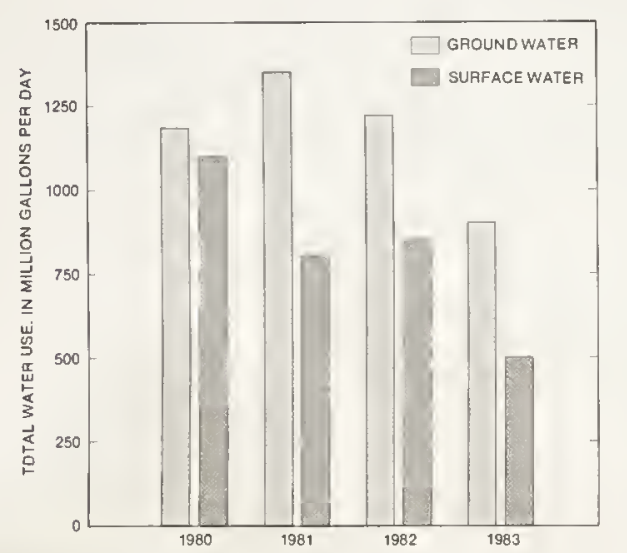

RICE IRRIGATION AMOUNTED TO SUNFLOWER AGALD IN BOLIVAR,

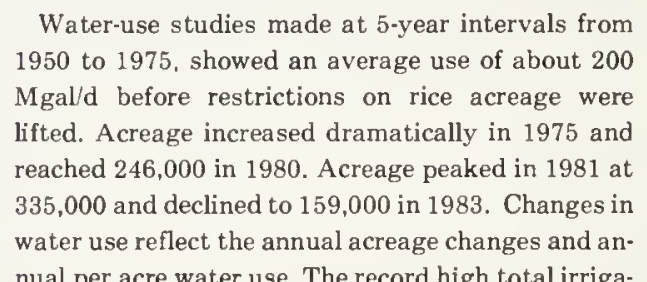

water use reflect the annual acreage changes and an. nual per acre water use. The record 1 tion use was $1,047 \mathrm{Mgald}$ in 1981.
to ION GALLONS OF WATER WA

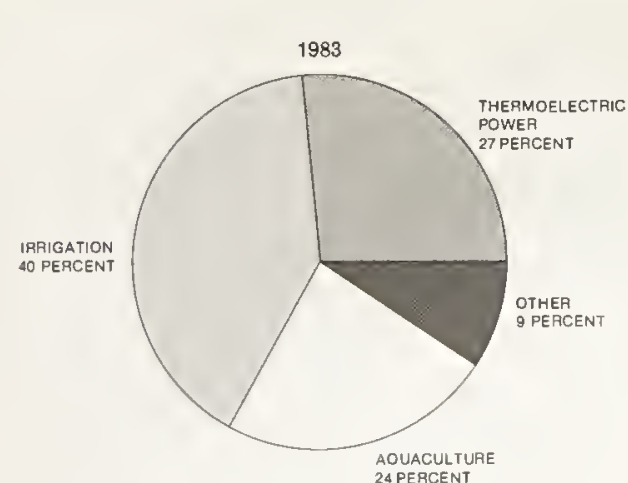

THE THREE PRINCIPAL WATER USES IN 1983 WERE IRRIGATION, THERNOELETRIC POWER

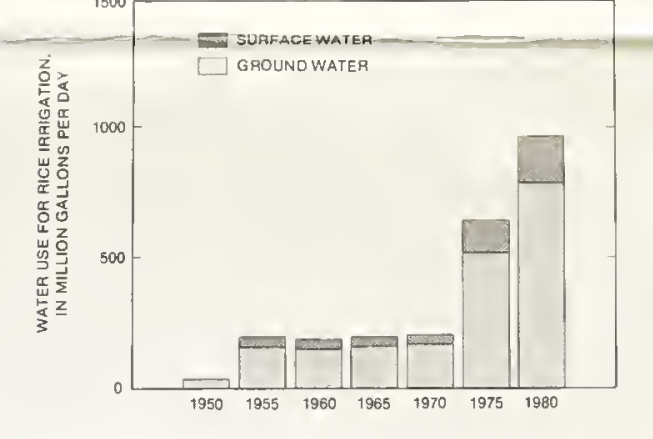

RICE IRRIGATION INCREASED

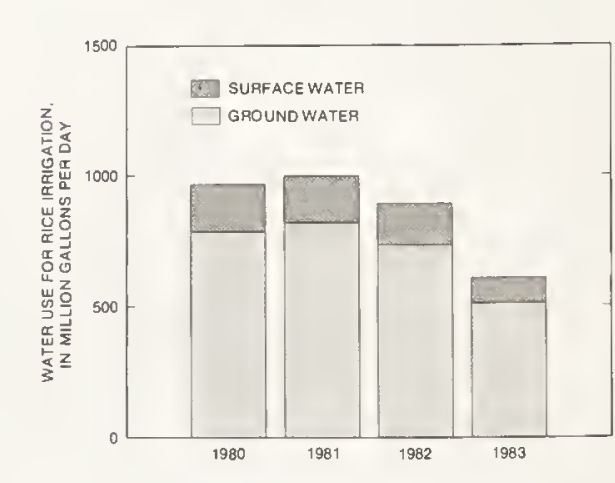

RICE IRRIGATION AVERAGED OVER

WATER USE IN THE DELTA COUNTIES OF MISSISSIPPI, 1983, BY PRINCIPAL

\begin{tabular}{|c|c|c|c|c|c|c|c|c|c|c|c|}
\hline & & $\begin{array}{l}\text { Sithifupp } \\
\text { ic Lives } \\
\text { ines }\end{array}$ & 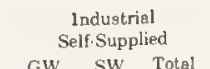 & 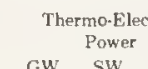 & & taturar & (a) & & $\begin{array}{l}\text { Wuallitie } \\
\text { Woundments }\end{array}$ & & 法 \\
\hline & & & & 0.43 & (2.1.02 & & $\begin{array}{lll}125.97 & 27.61 & 153.58\end{array}$ & & & & \\
\hline & $\begin{array}{l}2.0 .0 \\
2.0 .\end{array}$ & $\begin{array}{ll}200 & .12 \\
.00 & .19 \\
.04 & .08 \\
.08 & .13 \\
.04\end{array}$ & 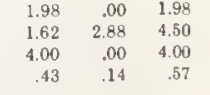 & $\begin{array}{l}2.86 \\
.00 \\
.00 \\
.00\end{array}$ & 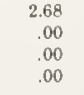 & 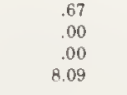 & 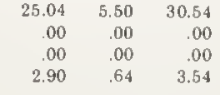 & 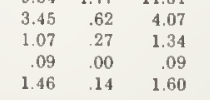 & $\begin{array}{l}.00 \\
.000 \\
.00 \\
.00 \\
.00 \\
-00\end{array}$ & 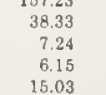 & \\
\hline & 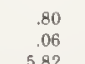 & $\begin{array}{l}.32 \\
.08 \\
.08 \\
.01 \\
.01\end{array}$ & 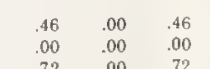 & . .00 & 然 & 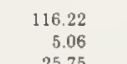 & $\begin{array}{ll}9.76 \\
\text { s.t. }\end{array}$ & & & 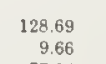 & \\
\hline & 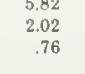 & 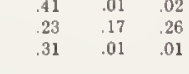 & 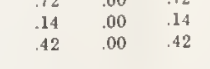 & 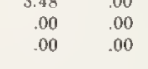 & 然 & 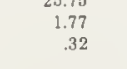 & 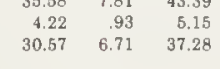 & 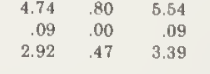 & 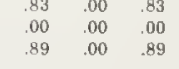 & 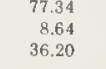 & 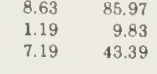 \\
\hline 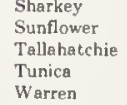 & 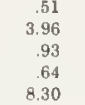 & 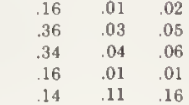 & 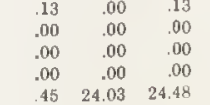 & 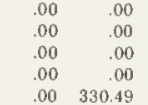 & $\begin{array}{l}.00 \\
\substack{.00 \\
\text { o. } \\
\text { soo } \\
30.49}\end{array}$ & 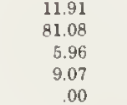 & 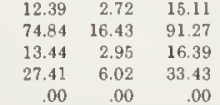 & 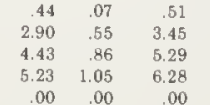 & & 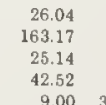 & \\
\hline $\begin{array}{l}\text { thingon } \\
\text { coton }\end{array}$ & 年6 & 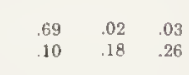 & $\begin{array}{ccc}6.29 & .00 \\
15.26 & 6.29 & .00 \\
155.26\end{array}$ & 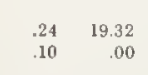 & $\begin{array}{l}19.56 \\
.10\end{array}$ & 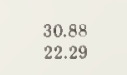 & 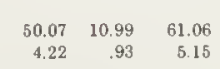 & 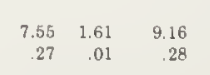 & 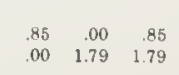 & $\begin{array}{l}1062.28 \\
40.14\end{array}$ & $\begin{array}{l}3.95 \\
2.99 \\
2\end{array}$ \\
\hline
\end{tabular}

HUMPHREYS AND SUNFLOWER 促 1983, ACCOUNTED FOR 59 PERCEN OF ALL WATER
AQUACULTURE.
(Dencipally catish farming) has resulted in Gestant we ter is the olly source used to mainten

In 1981, approximately 54,000 acres of ponds creage had increased to over 62,000, but the ground-water withdrawal decreased to about 332 ciently.

Water-use estimates are based on data acquired operations in the Delta. Improved management a chniques have reduced the water use application
and rate of water per pond acre from

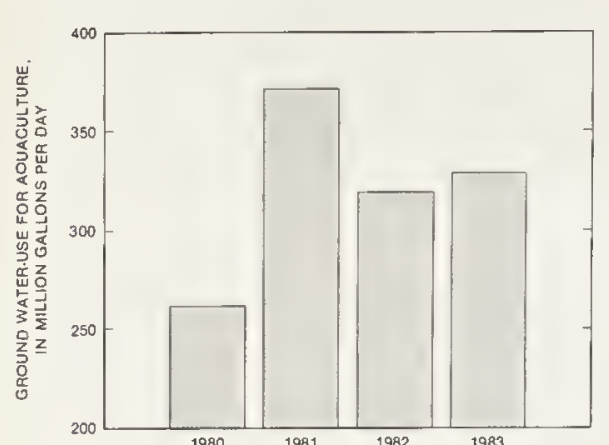

CATFISH PONDS USED MORE THAN
330 MGAL/D OF GROUND WATER IN

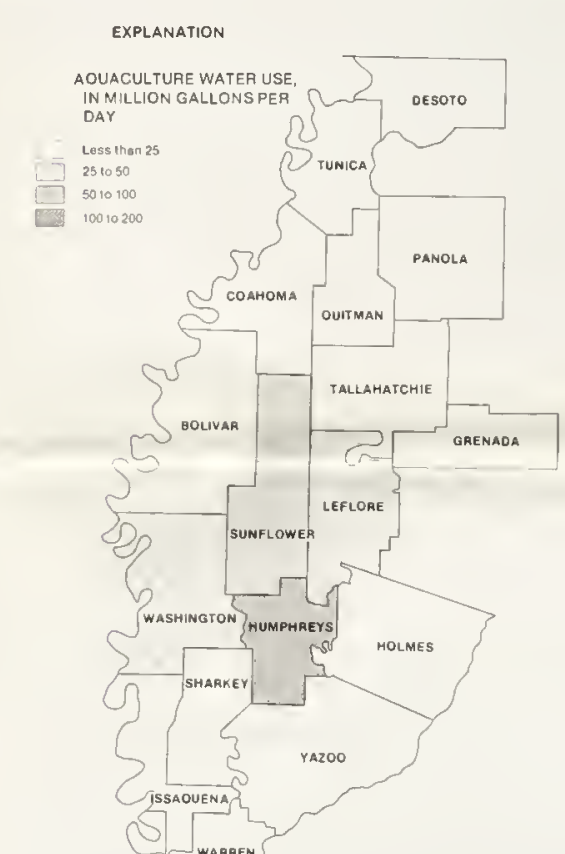

PUBLIC SUPPLY

The municipal, rural, and private water system 983. Included in this total are domestic, comm

Thermoelectric power plants are second to irrig
tion in water use in the Delta. Generating plants are sis. The three largest power plants use surface vater for cooling and ground water for maklep ourd The ground-water use at all power plan since 1980 .

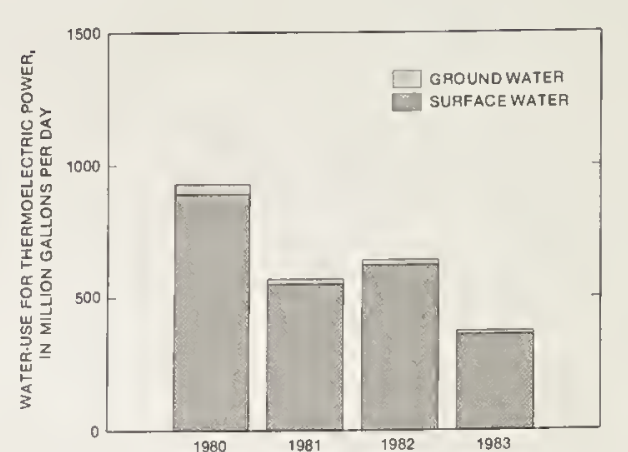

SURFACE WATER SOURCES SUP MOELECTRIC PLANTS-98 PERCENT OF THE TOTAL NEED
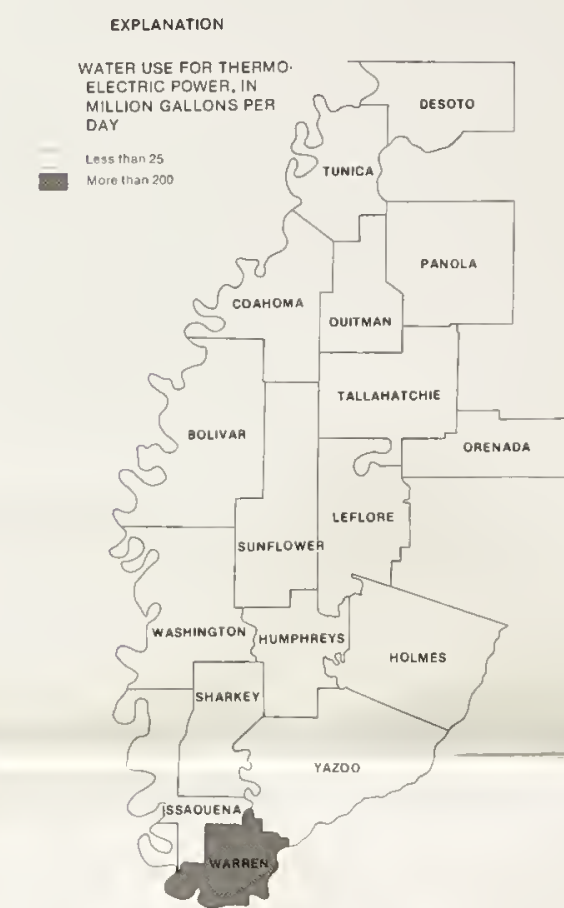

THERMOELECTRIC POWER GENERMAJOR USE OF WATER IN WARREN ON COUNTES WERE MINOR USE
WITH ABOUT 20 MGAL/D EACH.

\section{INDUSTRIAL SELF-SUPPLIED} withdrawals in 1983 from ground-water and surface-water sources a mounted to 62 Mgald (see table). Although many own a source of water supply, some are also conwater, sanitary purposes, and fire protection. In

\section{OTHER USES}

Combined ground-water and surface-water
withdrawals for wral welf poundments use (see table) accounted for about 1

\section{SELECTED REFERENCES} Callahan, J. A., 1983, Water use in Mississippi
1980: U.S. Geological Survey Open-File Report ississippi Department of Agriculture and Con 1980-1983: Mississippi Departurment of Af Agri-
culture and Commere, supplement 16, 60 p. Vissisippi Municipal Association, 1981. Missis.
sippi Municipal Directory, 1977-1981: Jackson sippi Municipal D.
Mississippi. 87 p.

Solley, W. B., Chase, E. B., Mann W. B., IV 1982, Estimated use of water in the United
States, 1980: U.S. Geological Survey Circular

U.S. Bureau of Census, 1981,1980 Census of popu
lation and housing: U.S. Department of

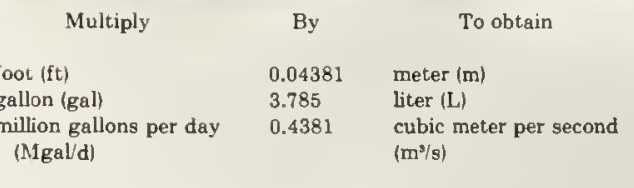
enerally used for coling on a netimethrous Commerce, Bureau of the Census PHC80-V.26,
Mississippi, 20 p 